Obě monografie - jak ve své úplnosti, tak i jejich jednotlivé části - mohou být úspěšně použity i v procesu výuky bulharského jazyka pro Čechy, resp. českého jazyka pro Bulhary, a to nejen během prrípravy budoucích vyučujících, ale i při samotné výuce praktické češtiny, resp. bulharštiny, neboť sledované morfologické kategorie rezultativ i relativ, jejichž osvojování ze strany Slovanů učících se jiný slovanský jazyk je pouze zdánlivě snadné, představují komplexně - stylově vysokým, avšak srozumitelným odborným jazykem. Uvedené monografie poskytují úplný obraz o jejich podstatě a možném užívání.

Elena Krejčová

\title{
Literatura:
}

STOJČEV, S.: Bălgarskijat morfologičen relativi češkijat ezik ili za săvremennija bălgarski morfologičen relativ i negovite funkcionalni ekvivalenti $v$ săvremennija češki ezik. Sofija: Izdatelstvo „Siluet“, 2019. ISBN 978-619-194-054-7.

STOJČEV, S.: Bălgarskijat morfologičen rezultativ $i$ češkijat ezik ili za săvremennija bălgarski morfologičen rezultativ i negovite funkcionalni ekvivalenti $v$ săvremennija češki ezik. Sofija: Izdatelstvo „Siluet“, 2019. ISBN 978-619-194-053-0.

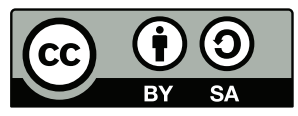

Toto dílo Ize užít v souladu s licenčními podmínkami Creative Commons BY-SA 4.0 International (<https:// creativecommons.org/licenses/by-sa/4.0/legalcode>). Uvedené se nevztahuje na díla či prvky (např. obrazovou či fotografickou dokumentaci), které jsou v díle užity na základě smluvní licence nebo výjimky či omezení príslušných práv.

\section{Bezpečnost silničního provozu v jazykovém obrazu světa dětí a mládeže}

WOJCIECHOWSKA, J.: Bezpieczeństwo drogowe w językowym obrazie świata dzieci i młodzieży. Bielsko-Biała: Wydawnictwo Naukowe ATH, 2018, $182 \mathrm{~s}$.

V roce 2018 vyšla v Polsku monografie Justyny Wojciechowské Bezpečnost silničního provozu v jazykovém obrazu světa dětí a mládeže - svým charakterem novátorská studie sjednocující úsilí jazykovědce a orgánů policie. Výsledkem této spolupráce je dílo, svým charakterem interdisciplinární, které je už proto neobyčejně pozoruhodné.

Ve svém výzkumu se autorka odvolává na mezinárodní dokumenty Evropského parlamentu a polské vlády, avšak - jak sama zdůrazňuje - klíčem k pochopení 
bezpečnosti nebo ohrožení zůstávají jazyková vyjádření. J. Wojciechowská popisuje chápání bezpečnosti silničního provozu v jazykovém obrazu dětí a mládeže a používá přitom interdisciplinární přístup lingvosekuritologie, která zkoumá jazyk bezpečnosti, prričemž ho začleňuje do antropocentrického paradigmatu. Její přístup vede též $\mathrm{k}$ odhalení současných výzev pro člověka $\mathrm{v}$ prostředí automobilového provozu. Výzkum je novátorský, atypický, rozšiřující ovšem chápání dopravní bezpečnosti do širšího sociálního kontextu.

Monografii tvoří 4 kapitoly. V první, nazvané Teoretické základy výzkumu, rozeznáváme interdisciplinární prrístup, který autorka uplatňuje - zpracovávají se tu statistické údaje, vysvětlují se legislativní texty. Velký dojem zanechává hluboká bibliografická obeznámenost autorky, jež se odrazila ve druhé kapitole Bezpečnost v současné odborné teorii. Jednotlivé části této kapitoly jsou věnovány bezpečnosti v jazykovém obrazu světa, mnohoznačnosti pojmu bezpečnost, lingvosekuritologie $\mathrm{v}$ perspektivě hodnocení bezpečnosti, kategoriím naivní věda a každodennost v jazyce, sociálně-kulturním základům vzdělávání apod. Tolik svým charakterem různorodé vědecké problémy jsou představeny kompaktně, jasně a vyčerpávajícím způsobem, což je i velká výhoda posuzované knihy. Třetí kapitola Terminologické problémy se zabývá ideovou mapou pojmu bezpečnost a sémantickým rozsahem termínu bezpečnost. Čtvrtá kapitola s názvem Bezpečnost silničního provozu z lingvistické perspektivy představuje již nespornou lingvistickou analýzu. Obsahuje detailní rozbor psaných textů školáků, přičemž se podrobně zabývá stereotypy, které se v nich vyskytují, a také metaforami v jazykovém obrazu dopravní bezpečnosti.

Na základě zkoumání jazykového materiálu autorka dochází k závěrům, že o kolik je věk respondentů vyšší, o tolik více negativní je jazykový obraz dopravní bezpečnosti. U dětí v předškolním věku se pohybuje v dimenzích pohádek a kouzel. $S$ vyšším věkem a nabýváním zkušeností a znalostí se stereotypní chápání transformuje do pocitu ohrožení. Praktický cíl monografie je explikace potřeb realizace konkrétních úkonů společnými silami celé společnosti. Právě to z ní dělá užitečné čtení nejen pro jazykovědnou obec, ale i pro mnohem širší okruh čtenářù.

Elena Krejčová

\section{Literatura:}

WOJCIECHOWSKA, J.: Bezpieczeństwo drogowe w językowym obrazie świata dzieci i młodzieży. Bielsko-Biała: Wydawnictwo Naukowe ATH, 2018.

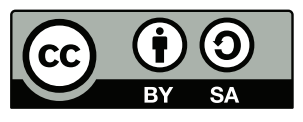

Toto dílo Ize užít v souladu s licenčními podmínkami Creative Commons BY-SA 4.0 International (<https:// creativecommons.org/licenses/by-sa/4.0/legalcode>). Uvedené se nevztahuje na díla či prvky (např. obrazovou či fotografickou dokumentaci), které jsou v díle užity na základě smluvní licence nebo výjimky či omezení př́slušných práv. 